\title{
Produksi Xilanase dari Isolat Sumber Air Panas Sonai, Sulawesi Tenggara, menggunakan Limbah Pertanian
}

\author{
Prima Endang Susilowati*), Sapto Raharjo, Desi Kurniawati, \\ Rahmawati Rahim, Sumarlin, dan Ardiansyah
}

Jurusan Kimia, Fakultas Matematika dan Ilmu Pengetahuan Alam, Universitas Haluoleo, Kendari 93232

Diterima 24-01-2012 Disetujui 13-08-2012

\begin{abstract}
Xylanase is the enzyme with prospec for hydrolysis hemicellulases. Many industry use xylanase thermostable. This processes require enzymes which are operationally stable at high temperature thus allowing e.g. easy mixing, better substrate solubility, high mass transfer rate, and lower risk of contamination. Thermophiles have often been proposed as sources of industrially relevant thermostable enzymes. Thermophilic bacteria, live at hot-springs, are can produced thermostable enzymes. In this work, we studied the bacteria strains isolated from water collected in the Sonai hot-springs of Southeast Sulawesi region and condition production enzyme. Screaning bacteria xylanolitic use semi-quantitative detection at agar plate with xilan, and quantitative detection activity enzyme. Result experinces in the 28 isolates screened, isolat IIA-3 (Pseudomonas sp.) showed the highest xylanase production. Organism efficiently used $2 \%$ rice straw as substrates. Pseudomonas sp. was used to hydrolyses rice straw at $50^{\circ} \mathrm{C}$, agitation $150 \mathrm{rpm}$ and $\mathrm{pH} 9$.
\end{abstract}

Keywords: agro-wastes, Sonai hot-springs, xylanase

\begin{abstract}
ABSTRAK
Xilanase adalah salah satu enzim yang memiliki prospek yang besar sebagai enzim penghidrolisis hemiselulosa. Beberapa industri memerlukan xilanase yang tahan pada suhu tinggi. Proses di industri memerlukan enzim yang aktif dan stabil pada suhu tinggi, sehingga memudahkan pencampuran, substrat mudah larut, mempercepat reaksi, dan mencegah kontaminasi. Salah satunya adalah mencari enzim termostabil yang dihasilkan oleh mikroorganisme termofilik. Mikroorganisme tersebut umumnya hidup di sumber air panas. Tujuan dari eksperimen ini adalah untuk mengisolasi dan menyeleksi bakteri yang dapat menghasilkan xilanase tinggi, serta menentukan kondisi produksi enzim. Seleksi dilakukan dengan penapisan semikuantitatif menggunakan deteksi pada plat agar mengandung substrat xilan dan penapisan kuantitatif dengan mengukur aktivitas enzim. Kondisi optimal produksi enzim dipelajari dengan menentukan jenis dan jumlah substrat, $\mathrm{pH}$ serta suhu. Hasil penapisan menunjukkan bahwa isolat IIA-3 yaitu Pseudomonas sp. memiliki aktivitas xilanase yang relatif tertinggi jika dibandingkan dengan 27 spesies yang lain. Pseudomonas sp. akan menghasilkan enzim xilanase optimum pada kondisi media mengandung substrat sekam padi $2 \%$ dan $\mathrm{pH} 9$, serta kondisi fermentasi adalah kecepatan shaker $150 \mathrm{rpm}$ pada suhu $50^{\circ} \mathrm{C}$.
\end{abstract}

Kata kunci: limbah pertanian, sumber air panas Sonai, xilanase

\section{PENDAHULUAN}

Xilanase merupakan enzim ekstraseluler yang mempunyai kemampuan menghidrolisis xilan (hemiselulosa) menjadi xilo-oligosakarida dan xilosa. Enzim ini terdiri dari endo- $\beta$-xilanase (EC 3. 2. 1. 8) dan $\beta$-xylosidases (EC 3. 2. 1. 37). Xilanase dapat dihasilkan oleh mikroba melalui proses fermentasi. Enzim xilanase diperlukan oleh beberapa industri

*Telp: +6281322087327

Email: primachem_kdi@yahoo.com antara lain industri pangan, pakan ternak, pemutih bubur kertas/pulp, dan biokonversi lignoselulosa untuk bahan bakar (Kim et al. 2000; Rifaat et al. 2005). Untuk mempercepat proses pada umumnya industri menggunakan suhu tinggi. Salah satunya pada industri kertas proses pembuatan bubur kertas dilakukan dengan pemanasan (Sirait 2003), agar enzim xilanase dapat ditambahkan tanpa harus dilakukan proses pendinginan maka diperlukan enzim xilanase termostabil. 
Hal ini dikarenakan enzim termostabil mampu mempertahankan aktivitasnya pada suhu tinggi.

Kebutuhan enzim xilanase di industri yang terus meningkat menyebabkan perlu dilakukan eksperimen untuk mencari sumber penghasil enzim xilanase yang tahan terhadap suhu tinggi. Alternatifnya mencari enzim xilanase termostabil yang dihasilkan oleh mikroorganisme berasal dari sumber air panas, seperti kawah gunung berapi, daerah geotermal. Mikroorganisme termofilik berpotensi untuk menghasilkan enzim termostabil, karena kemampuan enzim bekerja pada suhu tinggi dapat dipengaruhi oleh kondisi lingkungan di mana bakteri tesebut hidup (Ahmaloka et al. 2006).

Produksi enzim memerlukan kondisi optimum, yaitu $\mathrm{pH}$, suhu, kecepatan aerasi (aerasi) dan konsentrasi substrat. Penentuan $\mathrm{pH}$ kultivasi merupakan faktor yang penting untuk pertumbuhan mikroorganisme dan pembentukan produk metabolitnya. Lloyd dan Nelson (1984) menyatakan bahwa aktivitas optimum enzim berkisar pada $\mathrm{pH}$ pertumbuhan mikroorganisme penghasil enzim tersebut. Suhu juga berpengaruh langsung terhadap kecepatan pertumbuhan mikroorganisme, kecepatan sintesis enzim, dan kecepatan inaktivasi enzim. Aerasi berfungsi untuk mempertahankan kondisi aerobik untuk desorbsi $\mathrm{CO}_{2}$, mengatur temperatur substrat, dan mengatur kadar air (Richana et al. 2000).

Produksi xilanase oleh mikroorganisme memerlukan substrat sebagai penginduksi yaitu xilan. Secara ekonomi penggunaan xilan murni pada skala industri terlalu mahal, oleh karena itu perlu usaha untuk mencari sumber karbon yang relatif lebih murah. Limbah pertanian yang memiliki komponen utama lignoselulosa diharapkan dapat digunakan sebagai sumber karbon. Beberapa eksperimen untuk memanfaatkan limbah pertanian telah dilakukan, yaitu penggunaan kulit pisang, bonggol jagung, limbah gandum, bagas dan sekam padi untuk produksi xilanase (Reddy et al. 2003; Seyis \& Aksoz 2005; Okafor et al. 2007; Gupta \& Kar 2008).

Pada eksperimen ini dilakukan isolasi bakteri dari sumber air panas Sonai Sulawesi Tenggara yang berpotensi menghidrolisis xilan, serta mengoptimalkan kondisi untuk produksi enzim. Diharapkan dapat diperoleh substrat yang murah untuk produksi enzim xilanase sehingga dapat menekan biaya produksi rendah, sehingga akan membantu pengembangan bioindustri di Indonesia.

\section{BAHAN DAN METODE}

Isolasi dan Penapisan Bakteri Xilanolitik. Sampel diambil dari sumber air panas Sonai Sulawesi Tenggara pada 4 titik dengan karakteristik lingkungan yang berbeda. Isolasi bakteri dilakukan dengan metode dilution plate pada media Luria Berthani (LB) (Pepton 5\% (b/v), ekstrak yeast 2,5\% (b/v), $\mathrm{NaCl} 5 \%(\mathrm{~b} / \mathrm{v}), \mathrm{MgSO}_{4} .7 \mathrm{H}_{2} \mathrm{O}_{3} \%(\mathrm{~b} /$ v), $\left.\mathrm{H}_{3} \mathrm{BO}_{3} 1 \%(\mathrm{~b} / \mathrm{v}), \mathrm{CaCl}_{2} 1 \%(\mathrm{~b} / \mathrm{v}), \mathrm{Na}_{2} \mathrm{Mo}_{4} \cdot 2 \mathrm{H}_{2} \mathrm{O} 1 \%(\mathrm{~b} / \mathrm{v})\right)$. Setiap isolat yang tumbuh selanjutnya diisolasi dan diidentifikasi. Pemurnian isolat bakteri dilakukan dengan menumbuhkan koloni yang terpisah dan tampak jelas berbeda pada media agar LB. Identifikasi dilakukan dengan mengamati zona bening yang terbentuk pada media LB mengandung xilan 0,5\% (Sharma \& Bajaj 2005).

Preparasi Hemiselulosa. Penetapan kadar air, protein, kadar serat dan abu dilakukan menggunakan metode AOAC (2005) pada serbuk gergaji, ampas sagu dan sekam padi yang digunakan sebagai substrat pada media produksi xilanase. Delignifikasi limbah pertanian, dilakukan dengan cara sampel dicuci dengan air dan dipanaskan. Residu selanjutnya direndam dalam $2 \% \mathrm{NaOH}$ selama 2 jam, kemudian dicuci sampai $\mathrm{pH}$ netral. Sampel terdelignifikasi dikeringkan dalam oven suhu $80^{\circ} \mathrm{C}$ (Li et al. 2010).

Kondisi Proses Fermentasi untuk Produksi Xilanase. Isolat terpilih ditumbuhkan pada media LB mengandung limbah pertanian. Limbah pertanian yang digunakan adalah sekam padi, ampas sagu dan serbuk gergaji pada berbagai variasi konsentrasi. Sebanyak $5 \mathrm{ml}$ starter diinokulasikan ke dalam $50 \mathrm{ml}$ media LB mengandung limbah pertanian, selanjutnya difermentasi. Optimasi proses fermentasi meliputi pengamatan pengaruh suhu, $\mathrm{pH}$ dan kecepatan aerasi terhadap laju pertumbuhan bakteri dan produksi xilanase (Sharma \& Bajaj 2005). Interval untuk suhu $42-55^{\circ} \mathrm{C}$, pH 6-10, dan kecepatan goyong inkubator 125-175 rpm. Pengamatan dilakukan terhadap aktivitas enzim xilanase yang dihasilkan.

Pengujian Aktivitas Xilanase. Aktivitas xilanase diukur dengan mendeteksi gula pereduksi yang terbentuk menggunakan metode Dinitrosalicylic Acid (DNS) (Miller dalam Sharma \& Bajaj 2005). Aktivitas enzim diukur dengan mencampur $1 \mathrm{~mL}$ enzim, $1 \mathrm{~mL}$ substrat xilan $1 \%$, diinkubasi selama 60 menit. Inkubasi dihentikan dengan penambahan $2 \mathrm{~mL}$ pereaksi DNS, selanjutnya dipanaskan dalam air mendidih selama 30 menit. Setelah dingin 
ditambahkan akuades sampai volumenya $10 \mathrm{~mL}$. Absorbansi diukur pada panjang gelombang $520 \mathrm{~nm}$. Sebagai standar digunakan xilosa untuk menghitung aktivitas xilanase. Satu unit aktivitas xilanase dinyatakan sebagai banyaknya enzim yang diperlukan untuk menghasilkan $1 \mu$ mol gula xilosa dari substrat xilan per-menit.

Amplifikasi Gen 16sRNA menggunakan PCR. Isolat bakteri terpilih ditumbuhkan pada media LB mengandung xilan sampai mencapai fasa akhir logaritma. Sel bakteri disentrifugasi dengan kecepatan $5000 \mathrm{~g} 4^{\circ} \mathrm{C}$ selama 5 menit. Selanjutnya DNA sel bakteri diisolasi menggunakan metode Fermentas (2007). DNA hasil isolasi digunakan sebagai cetakan dalam proses PCR. Primer yang digunakan adalah 357f dan 907r yang akan menempel pada daerah hipervariabel gen 16sRNA (Tabel 1) (Yu \& Morrison 2004). Proses PCR dilakukan pada kondisi denaturasi $94^{\circ} \mathrm{C}$, anealing $42^{\circ} \mathrm{C}$, ekstention $72^{\circ} \mathrm{C}$, dan final ekstention $72^{\circ} \mathrm{C}$.

Analisis Filogenetik. Gen 16sRNA hasil amplifikasi selanjutnya ditentukan urutan nukleotidanya, dan selanjutnya digunakan untuk analisis filogenetik. Tahapan analisis filogenetik, yaitu: mengumpulkan urutan gen $16 \mathrm{~S}$ rRNA dengan bantuan Gen Bank melalui Basic Local Aligment Search Tool secara online pada www.nicbi.nlm.nih.gov. Metode untuk mensejajarkan urutan nukleotida dan melihat jarak kedekatan antar masing-masing sekuen dilakukan menggunakan program BLAST-N (Oehmen \& Nieplocha 2006). Dilanjutkan pembuatan pohon filogenetik menggunakan software MEGA (Kumar et al. 2001).

\section{HASIL DAN PEMBAHASAN}

Seleksi Mikroba Xilanolitik. Bakteri xilanolitik mampu memanfaatkan karbon dari limbah pertanian sebagai sumber energi, dengan cara menghasilkan enzim xilanase ekstraseluler untuk mendegradasi xilan yang terdapat di dalam media fermentasi. Indeks xilanolitik menunjukkan kemampuan degradasi mikroba terhadap xilan. Hasil eksperimen menunjukan isolat IIA-3 mepunyai indeks xilanolitik yang besar pada media mengandung xilan (Tabel 2 dan Gambar 1).

Data yang diperoleh mengindikasikan isolat II A-3 mampu menghidrolisis xilan menjadi molekul yang lebih sederhana, dan selanjutnya dipergunakan untuk proses metabolisme di dalam sel. Hidrolisis xilan terjadi karena isolat II A-3 menghasilkan enzim xilanase ekstraseluler. Oleh sebab itu semakin banyak enzim xilanase yang dihasilkan oleh bakteri xilanolitik, maka zona bening yang terbentuk akan semakin luas karena xilan yang terdegradasi semakin banyak.

Analisis Filogenetik. Penentuan genus suatu mikroorganisme dapat dilakukan melalui beberapa pendekatan, antara lain pengamatan mikroskop, pengujian biokimia, analisis gen 16sRNA. Analisis gen 16sRNA didasarkan pada urutan nukleotida pada gen 16sRNA, yang akan dibandingkan dengan data gen 16sRNA yang ada. Hasil analisis similaritas sekuen gen 16S rRNA isolat IIA-3 dengan data GenBank, diketahui homologi spesies dari isolat yang diuji memiliki kemiripan 92\% dengan Pseudomonas aeruginosa strain RSB3. Pada Gambar 2, terlihat isolat IIA-3 berada pada kelompok Pseudomonas aeruginosa strain NBRAJG70, Pseudomonas aeruginosa strain RSB3, Pseudomonas aeruginosa strain NBRAJG78, Pseudomonas aeruginosa strain AU3477, Pseudomonas aeruginosa strain NBAII AFP-4, Pseudomonas aeruginosa strain SML, Pseudomonas sp. 1S2, Pseudomonas aeruginosa strain LCB52, dan Pseudomonas aeruginosa strain: \#777. Berdasarkan analisis filogetenik, isolat IIA-3 termasuk domain: Bacteria, filum: Proteobacteria, kelas: Gammaproteobacteria, ordo: Pseudomonadales, famili: Pseudomonadaceae, dan genus: Pseudomonas sp. (Gambar 2).

Tabel 2 Indeks xilanolitik isolat Sonai

\begin{tabular}{lc}
\multicolumn{1}{c}{ Isolat mikroba } & Indeks xilanolitik \\
\hline I B-1 & 0,4 \\
II A-1 & 0,6 \\
II A-3 & 1,8 \\
II A-8 & 1,6 \\
\hline
\end{tabular}

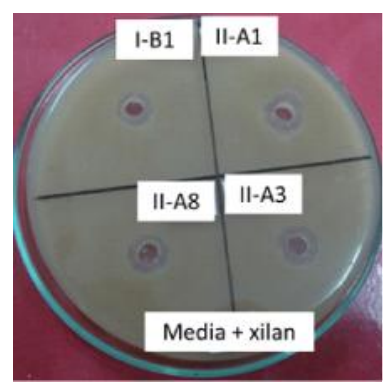

Gambar 1 Zona bening pada media mengandung xilan

Tabel 1 Primer amplifikasi gen 16s rRNA (Yu \& Morrison 2004)

\begin{tabular}{llcc}
\hline Primer & Urutan nukleotida $\left(5^{\prime} \rightarrow 3^{\prime}\right)$ & Posisi penempelan & Daerah target \\
\hline $357 \mathrm{f}$ & CCT ACG GGA GGC AGC AG & $341-357$ & V3 \\
$907 \mathrm{r}$ & CCG TCA ATT CCT TTG AGT TT & $907-926$ & V6-V8 \\
\hline
\end{tabular}




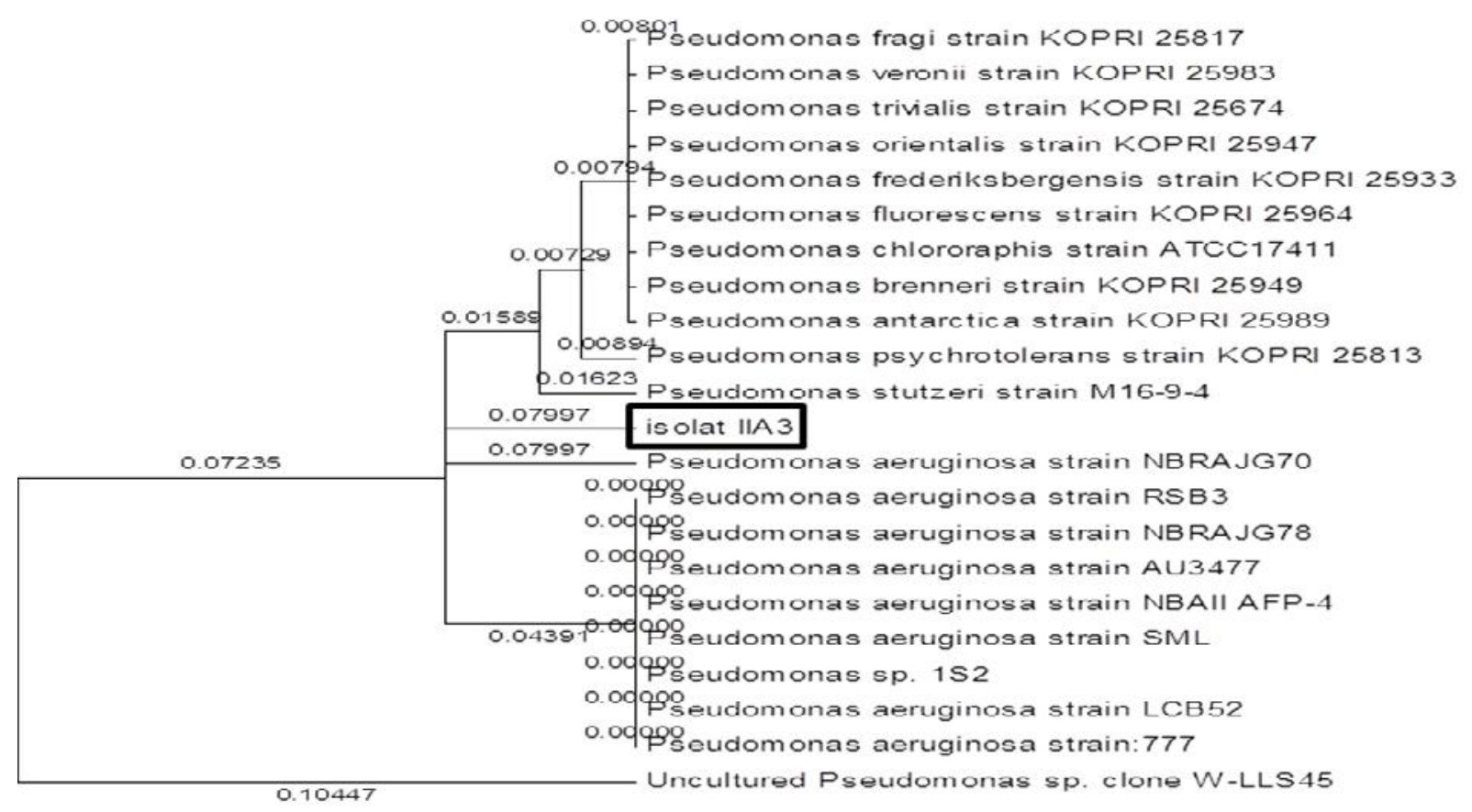

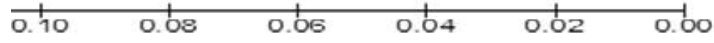

Gambar 2 Pohon filogenetik berdasarkan sekuen gen 16S rRNA dari isolat IIA-3

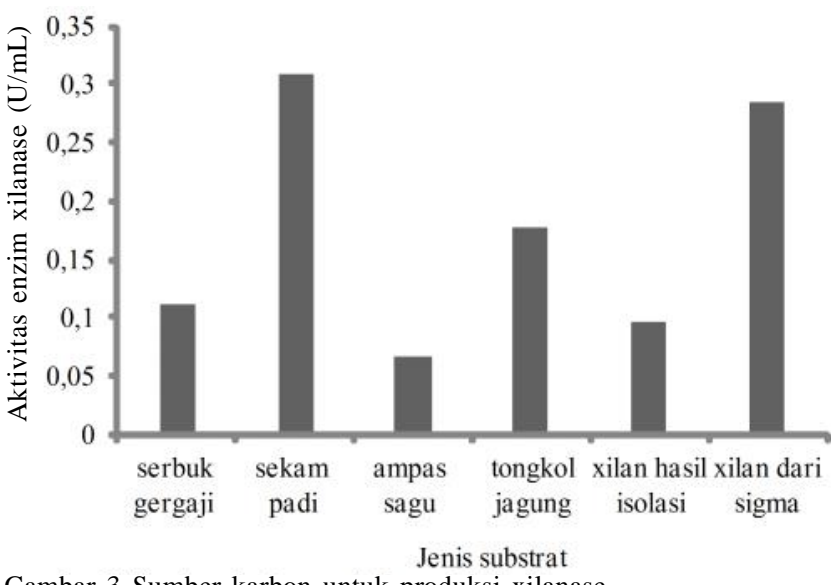

Gambar 3 Sumber karbon untuk produksi xilanase

Komposisi Medium Fermentasi. Medium fermentasi sangat mempengaruhi enzim yang dihasilkan. Produksi enzim xilanase memerlukan penginduksi yaitu xilan, karena keberadaan xilan pada medium fermentasi akan memicu bakteri mensekresikan enzim ekstraseluler yang dapat mengubah xilan menjadi molekul sederhana sebagai sumber karbon. Namun penggunaaan xilan murni dalam produksi xilanase skala besar terlalu mahal. Pada eksperimen ini dilakukan identifikasi sumber karbon untuk produksi xilanase dari limbah lignoselulosa, yaitu ampas sagu, sekam padi dan serbuk gergaji. Hasil eksperimen menunjukkan produksi enzim xilanase paling baik adalah pada media fermentasi mengandung sekam padi (Gambar 3).
Analisis proksimat menunjukan sekam padi merupakan substrat yang baik untuk produksi enzim xilanase, karena mengandung mineral (kadar abu), protein dan serat kasar cukup tinggi sehingga potensial digunakan sebagai media pertumbuhan bakteri dan produksi enzim (Tabel 3). Bakteri untuk pertumbuhannya memerlukan karbohidrat, protein dan mineral. Berdasarkan analisis proksimat sekam padi dan aktivitas enzim yang dihasilkannya menunjukan komponen pada sekam padi cukup tepat untuk memenuhi kebutuhan hidup isolat IIA-3.

Jumlah serat kasar yang terdapat pada sekam padi menunjukkan tidak sebesar pada serbuk gergaji (Tabel 3). Namun sudah dapat menginduksi isolat IIA-3 untuk menghasilkan enzim xilanase ekstraseluler (Gambar 3). Isolat IIA-3 tidak dapat secara langsung menggunakan serat kasar untuk memenuhi kebutuhan karbohidrat, sehingga harus ada mekanisme pengubahan menjadi gula sederhana dengan bantuan enzim ekstraseluler yang dihasilkannya. Salah satu enzim ekstraseluler adalah enzim xilanase. Enzim ini diekskresikan oleh mikroorganisme untuk menghidrolisis xilan (polisakarida) yang terdapat pada media menjadi molekul gula sederhana yang akan dimetabolisme di dalam sel. Oleh karena itu substrat yang digunakan dalam media fermentasi berpengaruh terhadap aktivitas dan produktivitas enzim. Adanya substrat tertentu dalam medium 
Tabel 3 Komposisi limbah lignoselulosa

\begin{tabular}{lccc}
\multicolumn{1}{c}{ Limbah pertanian } & Kadar air (\%) & Kadar abu (\%) & Kadar serat kasar (\%) \\
\hline 1. Sekam Padi & 7,71 & 8,79 & 27,25 \\
2. Ampas Sagu & 70,54 & 2,99 & 18,25 \\
3. Serbuk Gergaji & 16,19 & 1,04 & 1,17 \\
\hline
\end{tabular}

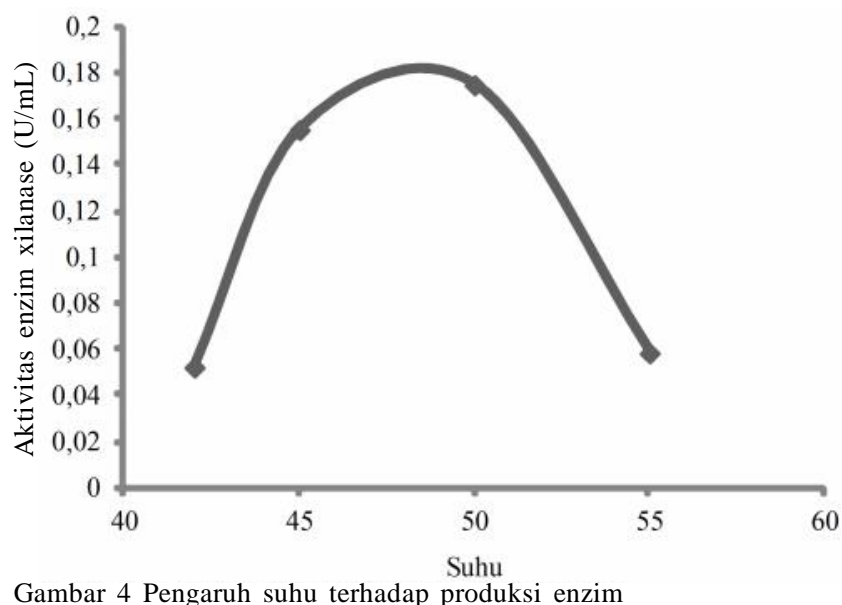

produksi dapat memacu mikroorganisme untuk mensekresi metabolit selnya, termasuk enzim ekstraseluler.

Optimalisasi Kondisi Produksi Enzim. Penentuan suhu dan $\mathrm{pH}$ kultivasi merupakan faktor penting untuk pertumbuhan mikroorganisme dan pembentukan produk metabolitnya. Sebelum memproduksi enzim dalam bioreaktor perlu dilakukan optimasi kondisi proses, yaitu variasi suhu, $\mathrm{pH}$ dan kecepatan aerasi. Hasil eksperimen menunjukan pada suhu $50^{\circ} \mathrm{C}$, pH 9 dan kecepatan aerasi $150 \mathrm{rpm}$, isolat IIA-3 memproduksi enzim xilanase dengan aktivitas tertinggi pada media mengandung sekam padi (Gambar 4 dan 5).

Suhu sangat mempengaruhi kecepatan pertumbuhan mikroorganisme, kecepatan sintesis enzim dan kecepatan inaktivasi enzim (Knob \& Carmona 2008). Hasil eksperimen menujukan isolat IIA-3 termasuk bakteri termofilik karena mampu hidup pada suhu $50^{\circ} \mathrm{C}$ (Gambar 4). Dari isolat ini diharapkan dapat diperoleh enzim xilanase yang mempunyai aktivitas pada suhu tinggi, karena umumnya enzim termofilik dapat dihasilkan oleh mikroorganisme yang dikulturkan pada suhu optimal di atas $45^{\circ} \mathrm{C}$. Selain itu umumnya aktivitas enzim yang dihasilkan oleh mikroorganisme termofilik memiliki suhu optimal di atas suhu pertumbuhannya (Rawashdeh et al. 2005; Fadel 2001).

Aktivitas enzim xilanase yang dihasilkan optimum, bila isolat IIA-3 ditumbuhkan pada medium dengan $\mathrm{pH}$ 9, yaitu $0,25 \mathrm{U} / \mathrm{mL}$ (Gambar 5). Pengaruh $\mathrm{pH}$ medium pada produksi enzim diuji pada jam dengan aktivitas tertingginya. Mikroorganisme akan tumbuh dan menghasilkan metabolit sekunder pada kondisi yang sesuai, salah satunya adalah
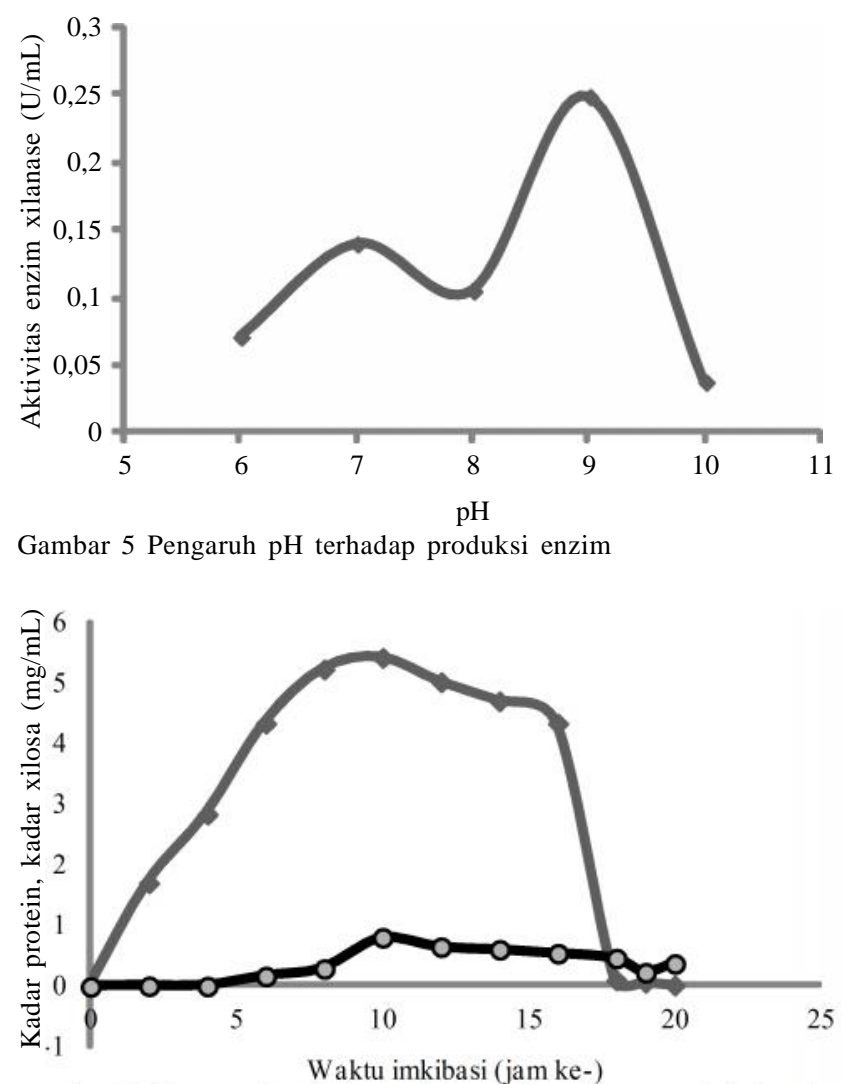

Gambar 6 Kurva pertumbuhan pada kondisi optimum produksi enzim xilanase. $\bullet$ : kadar protein; o: kadar xilosa

tingkat keasaman medium. Pada kondisi keasaman di bawah atau di atas $\mathrm{pH}$ optimum dapat mempengaruhi enzim yang dihasilkan karena protein dapat terdenaturasi, sehingga sisi aktif enzim tidak dapat bereaksi dengan substrat.

Aerasi berfungsi untuk mempertahankan kondisi aerobik dan mengatur temperatur substrat tetap konstan. Kondisi aerobik dipertahankan dengan mengatur tingkat oksigen yang dibutuhkan untuk sintesis produk, jumlah panas metabolik yang harus dihilangkan dari bahan, ketebalan lapisan substrat, tingkat $\mathrm{CO}_{2}$ dan metabolitmetabolit lain yang mudah menguap harus dihilangkan, dan tingkat ruang udara yang tersedia di dalam substrat (Richana 2000). Tingkat aerasi sangat dipengaruhi oleh sifat mikroorganisme. Pada penelitian pendahuluan telah diketahui isolat IIA-3 adalah bakteri aerobik, oleh karena itu memerlukan aerasi untuk mempertahankan kondisi aerobik. Hasil eksperimen menunjukan pada kecepatan aerasi $150 \mathrm{rpm}$, menghasilkan enzim xilanase paling baik yaitu $0,1723 \mathrm{U} / \mathrm{mL}$. 
Mikroorganisme mempunyai waktu tumbuh bervariasi bergantung pada aktivitas metabolismenya. Fase pertumbuhan mikroorganisme diawali fase adaptasi, selanjutnya aktivitas metabolisme akan meningkat dan setelah mikroorganisme melewati fase puncak pertumbuhannya maka aktivitas metabolismenya akan menurun. Fase penurunan ini disebut fase kematian. Fase-fase pertumbuhan tersebut sangat berpengaruh terhadap enzim yang dihasilkan oleh mikroorganisme. Pada Gambar 5 terlihat bahwa aktivitas enzim xilanase meningkat seiring dengan pertumbuhan selnya. Namun ketika sel telah melewati fase stasioner, maka aktivitas enzim xilanase menurun. Hasil eksperimen menunjukan waktu optimum produksi enzim xilanase dari isolat IIA-3 adalah pada fase akhir logaritmik yaitu jam ke-10 waktu fermentasi (Gambar 6). Hal ini ditunjukan dengan aktivitas enzim xilanase tertinggi dibandingkan dengan jam yang lain.

\section{SIMPULAN}

Berdasarkan hasil eksperimen telah ditemukan bakteri Pseudomonas sp. potensial xilanolitik dari sumber air panas Sonai, Sulawesi Tenggara. Sekam padi dapat dimanfaatkan sebagai sumber karbon pada media produksi xilanase. Kondisi produksi enzim xilanase adalah suhu $50^{\circ} \mathrm{C}, \mathrm{pH} 9$ (alkali) dan kecepatan aerasi $150 \mathrm{rpm}$.

\section{UCAPAN TERIMA KASIH}

Eksperimen ini didukung oleh dana penelitian Hibah Bersaing Dikti. Dengan kontrak: No. 91b/H.29.10/P6/2011 tanggal 4 April 2011.

\section{DAFTAR PUSTAKA}

Ahmaloka, Suharto, A., Nurbaiti, S., Tika, I.N \& Warganegara, F.M. 2006. Ribotyping Identification of thermophilic bacterium from papandayan crater. Proceeding of ITB Engineering Science.

AOAC. 2005. Official Methods of Analysis of the Association of Official Analytical Chemist. Virginia: The Association of official Analytical Chemist.

Fadel, M. 2001. High-level xylanase production from sorghum flour by a newly isolate of Trichoderma harzianum cultivated under solid state fermentation. Annals of Microbiology 51: 61-78.

Fermentas. 2007. Genomic DNA purification kit.

Gupta, U \& Rita, K. 2008. Optimization and scale up of cellulase free endo xylanase production by solid state fermentation on corn cob and by immobilized cells of a thermotolerant bacterial isolate. JJBS 1(3): 129-134.
Kim, J.H., Kim, S.C \& Nam, S.W. 2000. Constitutive overexpression of the endoxylanase gene in Bacillus subtilis. J Microbiol Biotechnol 10: 551-553.

Knob, A \& Carmona, E.C. 2008. Xylanase production by Penicillium sclerotiorum and its characterization. World Applied Sciences Journal 4(2): 277-283.

Kumar, S., Tamura, K., Jakobsen, I.B \& Nei, M. 2001. MEGA2: molecular evolutionary genetics analysis software. Bioinformatics 17: 1244-1245.

Li, M.F., Fan, Y.M., Sun, R.C \& Xu, F. 2010. Characterization of extracted lignin of bamboo (Neosinocalamus affinis) preteaded with sodium hydroxide/urea solution at low temperature. BioResources 5(3): 1762-1778.

Lloyd, N.E \& Nelson, W.J. 1984. Glucose and Fructose Containing Sweeteners from Starch. Di dalam Whesler et al. (Eds.). Starch. Chemistry and Technology. Academic Press.

Oehmen, C \& Nieplocha, J. 2006. ScalaBLAST: A scalable implementation of BLAST for high-performance dataintensive bioinformatics analysis. IEEE Transactions on Parallel \& Distributed Systems 17(8): 740-749.

Okafor, UA., Okochi, V.I., Onyegeme-Okerenta, B.M \& Nwodo-Chinedu, S. 2007. Xylanase production by Aspergillus niger ANL 301 using agro-wastes. Afr J Biotechnol 6(14): 1710-1714.

Rawashdeh, R., Saadoun, I \& Mahasneh,A. 2005. Effect of cultural conditions on xylanase production by Streptomyces $s p$. (strain Ib 24D) and its potential to utilize tomato pomace. Afr J Biotechnol 4(3): 251-255.

Reddy, G, Babu, P.R., Komaraih P., Roy K.R.R.M \& Kothari, I.L. 2003. Utilization of banana waste for the production of lignolytic and cellulolytic enzymes by solid substrate fermentation using two Pleurotus species (P. ostreatus and $P$. sajorcaju). Process Biochem 381: 457-1462.

Richana, N. Lestari, P., Thontowi, A \& Rosmimik. 2000. Seleksi isolat bakteri lokal p[enghasil xilanase. Jurnal Mikrobiologi Indonesia 5(2): 54-56.

Rifaat, H.M., Nagieb, Z.A \& Ahmed, Y.M. 2005. Production of xylanases by Streptomyces species and their bleaching effect on rice straw pulp. App Ecol env Res 4(1): 151-160.

Seyis, I \& Aksoz, N. 2005. Xylanase Production from Trichoderma harzianum. Food Technol. Biotechnol 43(1): 37-40.

Sharma, P \& Bajaj, B.K. 2005. Production and partial characterization of alkali-tolerant xylanase from an alkalophilic Stretomyces sp. CD 3. J Sci Ind Res 64: 688697.

Sirait, S. 2003. Bleaching. Toba Samosir. PT. Toba Pulp Lestari, Training and Development Centre.

Yu, Z \& Morrison, M. 2004. Comparisons of different hypervariable regions of rrs genes for use in fingerprinting of microbial communities by PCRdenaturing gradient gel electrophoresis. Appl Environ Microbiol 70(8): 4800-4806. 